\title{
Pengaruh Teknik Shaping untuk Membentuk Kemampuan Menggosok Gigi Secara Mandiri pada Siswa Tunagrahita Sedang
}

\author{
Diyah Rohma Wati' ${ }^{1}$, Wiwik Dwi Hastuti \\ ${ }^{1}$ SLB Smart School Pacet Mojokerto \\ ${ }^{2}$ Universitas Negeri Malang \\ Email : diyahrahma0@gmail.com
}

\begin{abstract}
Abstrak : Penelitian ini bertujuan untuk mendeskripsikan kemampuan menggosok gigi anak tunagrahita sedang sebelum dan sesudah diberikan intervensi berupa teknik shaping. Penelitian dilakukan kepada anak tunagrahita sedang berjenis kelamin perempuan usia 14 tahun kelas 5 SDLB. Subjek tersebut memiliki kemampuan bina diri yang kurang dikarenakan dalam kehidupan sehari hari masih dibantu dengan orang tua untuk melakukan kegiatan bersih diri. Metode penelitian yang digunakan adalah single subject research dengan desain A-B-A. Analisis data yang digunakan pada penelitian ini adalah analisis dalam kondisi dan analisis antar kondisi. Hasil penelitian ini membuktikan bahwa teknik shaping berpengaruh untuk membentuk kemampuan menggosok gigi anak tunagrahita. Berdasarkan hasil penelitian ini, diharapkan pembelajaran bina diri yang dilakukan oleh guru maupun orang tua dapat menggunakan teknik pembelajaran yang sesuai sehingga memudahkan anak tunagrahita untuk memahami.

Kata Kunci : teknik shaping, kemampuan menggosok gigi, tunagrahita sedang.
\end{abstract}

\begin{abstract}
This research aims to describe the ability to brushing a child's teeth with moderate intellectual disability before and after being given intervention in the form of shaping technique. The research was conducted to children with moderate intellectual disability of girls aged 14 years 5 th grade SDLB. The subject has the ability of self-help is less due to the daily life is still assisted by parents to conduct clean activities herselves. The research method used is single subject research with A-B-A design. Data analysis used in this research is analysis in-condition and analysis between-condition The results of this research prove that shaping techniques have an effect to form the ability to brushing the child's teeth with moderate intellectual disability. Based on the results of this research, it is expected that self-help learning conducted by teachers and parents can use appropriate learning techniques that make it easier for children with moderate intellectual disability to understanding.

Keyword : shaping technique, brushing teeth ability, childern with moderate intellectual disability.
\end{abstract}

Tunagrahita adalah salah satu kondisi anak yang mengalami hambatan dalam segi intelektual. Tingkat kecerdasan pada anak tunagrahita adalah $\leq 70$. American Association on Intellectual and Developmental Disabilities (AAIDD) menyebutnya dengan istilah intellectual disability. American Association on Intellectual and Developmental Disabilities (AAIDD) mengemukakan bahwa intellectual disability is a disability characterized by significant limitations in both intellectual functioning and in adaptive behavior, which covers many everyday social and practical skills. This disability originates before the age of 18. Yang berarti bahwa tunagrahita adalah keterbatasan yang ditandai dengan ketidakmampuan yang signifikan dalam fungsi intelektual dan dalam perilaku adaptif, yang mencakup banyak keterampilan sosial dan kegiatan sehari-hari. Keterbatasan ini terjadi sebelum usia 18 tahun. Kemudian Somantri (2012) berpendapat bahwa tunagrahita merupakan suatu istilah penyebutan untuk anak yang memiliki kemampuan di bawah rata-rata. Anak tunagrahita yang memiliki keterbatasan dalam kecerdasannya mengakibatkan dirinya sulit untuk mengikuti program pembelajaran klasikal di sekolah seperti biasanya, oleh sebab itu anak tunagrahita membutuhkan pelayanan pendidikan secara khusus yang disesuaikan dengan kemampuan anak tersebut. Berdasarkan pendapat dari beberapa ahli tersebut, dapat disimpulkan bahwa definisi anak tunagrahita adalah mereka yang mempunyai hambatan pada segi intelektual, yang di mana tingkat kecerdasan mereka di bawah anak pada umumnya Salah satu ketidakmampuan peserta didik tunagrahita yang disebabkan keterbatasan intelektualnya adalah dalam perilaku adaptif. Perilaku adaptif meliputi merawat diri, mengurus diri, menolong diri, komunikasi, adaptasi, lingkungan, penggunaan waktu luang, dan keterampilan sederhana. Untuk meningkatkan kemampuan mereka maka perlu adanya pengembangan program bina diri. Menurut Kementrian Pendidikan dan Kebudayaan (2014), pengembangan program bina diri merupakan hal yang sangat penting untuk mengantarkan peserta didik tunagrahita dalam melakukan pengembangan dirinya, program pengembangan diri merupakan kegiatan pembelajaran bagi peserta didik tunagrahita dalam hal merawat diri, mengurus diri, menolong diri, berkomunikasi, bersosialisasi keterampilan hidup,dan mengisi waktu luang. Sedangkan Wantah (2007) mengemukakan bahwa bina diri merupakan salah 
satu proses pendidikan yang diberikan kepada anak tunagrahita sedang agar mampu mengembangkan kemampuan yang dimilikinya, seperti mengurus diri sendiri, makan, minum, membersihkan diri, menggunakan toilet sendiri, dan lain-lain, memilih pakaian yang cocok, dapat mengancing pakaian sendiri, sesama anak tunagrahita dan anak normal pada umunya. Berdasarkan pendapat dari berbagai ahli tersebut dapat disimpulkan bahwa bina diri merupakan salah satu program yang ditujukan kepada anak tunagrahita agar mampu untuk mengembangkan diri sehingga berguna baik untuk dirinya sendiri maupun untuk kehidupan bermasyarakat yang meliputi halhal dan kebutuhan manusia yang paling mendasar. Menurut Rochjadi (2014) pendekatan yang dipakai dalam pengembangan program bina diri bersifat perbaikan perilaku (behaviour modification).

Salah satu teknik yang digunakan untuk perbaikan perilaku adalah teknik shaping. Miltenberger (2016) mengemukakan bahwa Shaping is used to develop a target behavior that a person does not currently exhibit. Shaping is defined as the differential reinforcement of successive approximations of a target behavior until the person exhibits the target behavior, yaitu shaping digunakan untuk mengembangkan target perilaku yang belum dimunculkan oleh seseorang. Shaping didefinisikan sebagai penguatan diferensial secara berurutan sampai orang tersebut menunjukkan target perilaku. Sedangkan Rahmawati (2009) memberikan pendapat bahwa shaping merupakan proses penguasaan respon yang dikehendaki (dikondisikan), ketika pembentukan perilaku merupakan pemberian reinforcement setelah sukses melaksanakan apa yang diinginkan melewati serangkain perilaku yang diulangi untuk menjadi lebih baik lagi. Jadi, dapat disimpulakan bahwa shaping adalah salah satu teknik yang digunakan dalam modifikasi perilaku untuk membentuk perilaku baru individu yang belum pernah dilakukan sebelumnya. Shaping merupakan suatu bentuk pemberian penguatan yang dilakukan secara bertahap sampai target perilaku dapat terbentuk.

Hal-hal yang perlu diperhatikan jika akan menggunakan teknik shaping untuk membentuk perilaku adalah 1) melakukan analisis tingkah laku tersebut menjadi unit-unit kecil perilaku yang mendukung perilaku yang mendukung perilaku yang diharapkan tersebut ke dalam urutan perilaku secara linier, 2) hadiah-hadiah (reward) apa yang harus diberikan bila telah mencapai unit-unit tersebut. Di dalam shaping terdapat pengisyaratan untuk pembentukan perilaku. Pengisyaratan ini disebut prompting. Promprting adalah kegiatan melakukan stimuli prompt atau cara yang diberikan kepada siswa yang membutuhkan bantuan atau dorongan untuk menghasilkan respons yang benar. Jenis-jenis prompting meliputi 1) lisan (verbal prompt), 2) model atau contoh (modelling prompt), 3) fisik (Physical prompt), dan 4) isyarat (gestural prompt).
Pengembangan program bina diri merupakan salah satu proses pendidikan yang diberikan kepada anak tunagrahita sedang agar mampu mengembangkan kemampuan yang dimilikinya. Berdasarkan hasil pengamatan yang dilakukan di SLB Smart School Pacet Mojokerto, terdapat salah satu siswa tunagrahita sedang yang memiliki kemampuan bina diri yang cukup rendah terutama pada kemampuan menggosok gigi. Hal tersebut dikarenakan pada kehidupan seharihari anak tersebut masih dibantu oleh orang tua untuk melaksanakan kegiatan merawat diri. Selain itu, pelakasanaan program pengembangan bina diri di sekolah juga belum maksimal dikarenakan jarang dilakukan karena keterbatasan jumalah pengajar serta keterbatasan fasilitas seperti media pembelajaran. Hal tersebut mengakibatkan kemampuan bina diri pada anak belum dapat berkembang. Penelitian ini bertujuan untuk 1) mendeskripsikan kemampuan menggosok gigi anak sebelum diberikan intervensi berupa teknik shaping, 2) mendeskripsikan kemampuan menggosok gigi anak setelah diberikan intervensi berupa teknik shaping, dan 3) mendeskripsikan pengaruh teknik shaping terhadap kemampuan menggosok gigi anak tunagrahita sedang.

\section{METODE}

Metode penelitian merupakan salah satu prosedur dalam penelitian untuk kegiatan pengumpulan data dengan tujuan serta kegunaan tertentu. Metode yang digunakan dalam penelitian ini adalah metode Eksperimen. Sunanto,dkk (2005) mengemukakan bahwa secara garis besar desain penelitian eksperimen dibedakan menjadi dua kelompok, yaitu (1) desain kelompok (group desain) dan (2) desain subjek tunggal (singel subject research). Metode penelitian yang digunakan dalam penelitian ini adalah single subject research dengan desain A-B-A. Subjek pada penelitian ini adalah seoang anak tunagrahita sedang yang berjenis kelamin perempuan usia 14 tahun kelas 5 SDLB di SLB Smart School Pacet Mojokerto yang disertai dengan Down Syndrome. Siswa tersebut memiliki kemampuan bina diri yang rendah terutama pada menggosok gigi. Instrumen penelitian yang digunakan adalah lembar observasi berupa checklist task analysis yang berisi langkah-langkah menggosok gigi.

Adapun langkah-langkah menggosok gigi pada penelitian ini adalah (1) menyiapkan air di dalam cangkir untuk berkumur, (2) memegang sikat gigi dengan benar, (3) membuka tutup pasta gigi, (4) mengoleskan pasta gigi ke bulu sikat gigi, (5) berkumur, (6) menggosok gigi mulai dari bagian depan, samping, dalam dengan gerakan yang benar dan tekanan yang wajar, (7) berkumur sampai bersih, (8) melap mulut, (9) menyimpan peralatan dan bahan yang digunakan pada tempatnya. 
Tabel 1. Analisis Visual Dalam Kondisi

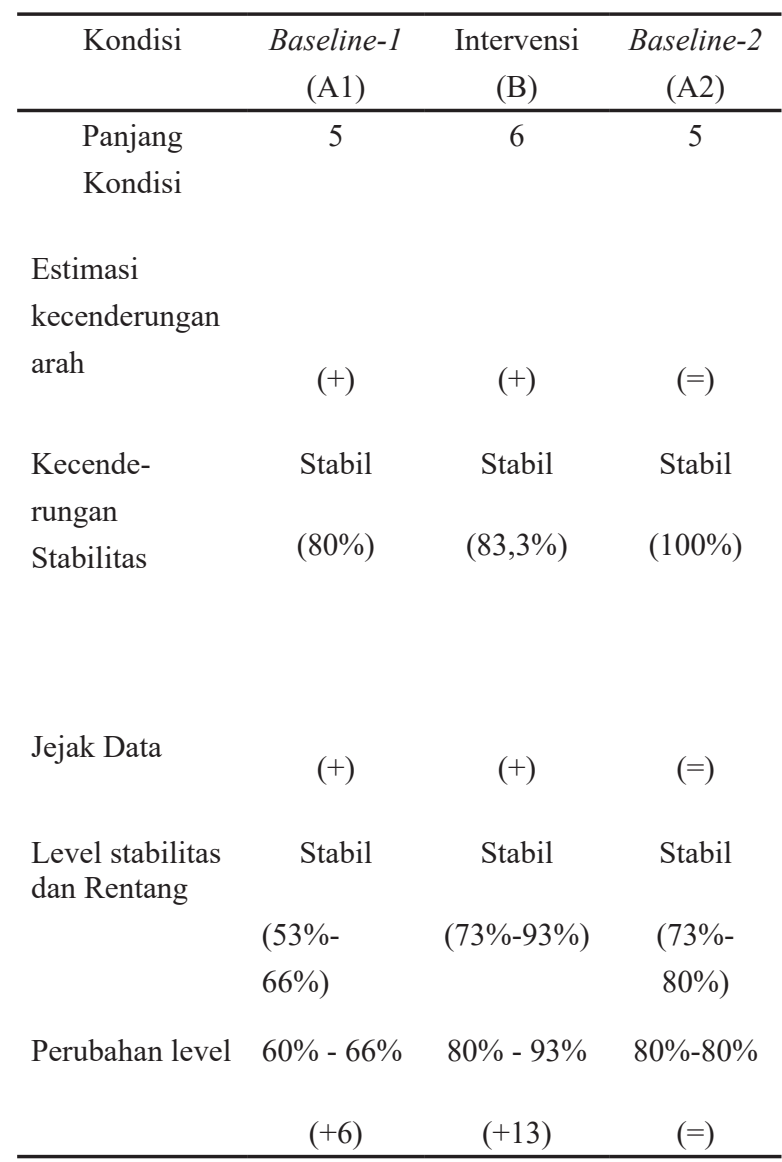

Tabel 2. Analisis Visual Antar Kondisi

\begin{tabular}{lcc}
\hline $\begin{array}{l}\text { Perbandingan } \\
\text { Kondisi }\end{array}$ & $\mathrm{B} / \mathrm{A} 1$ & $\mathrm{~A} 2 / \mathrm{B}$ \\
\hline $\begin{array}{l}\text { Jumlah Variabel } \\
\text { yang Diubah }\end{array}$ & 1 & 1 \\
$\begin{array}{l}\text { Perubahan } \\
\text { Kecenderungan }\end{array}$ & $(+)$ & $(+)$ \\
Arah dan & & \\
Efeknya & & \\
$\begin{array}{l}\text { P e r u b a h a n } \\
\text { Stabilitas }\end{array}$ & Stabil ke stabil & Stabil ke stabil \\
Perubahan Level & $80 \%-66 \%$ & $80 \%-93 \%$ \\
& $(+14)$ & $(-13)$ \\
$\begin{array}{l}\text { P r e s e n t a s e } \\
\text { Overlap }\end{array}$ & $0 \%$ & \\
\hline
\end{tabular}

Jenis pengukuran variabel terikat yang digunakan pada penelitian ini adalah persentase. Analisis data yang digunakan pada penelitian ini adalah analisis dalam kondisi dan analisis antar kondisi. Analisis dalam kondisi meliputi: (a) panjang kondisi, (b) estimasi kecenderungan arah (c) kecenderungan stabilitas, (d) jejak data, (e) level stabilitas dan rentang, dan (f) level perubahan, serta analisis antar kondisi yang meliputi: (a) jumlah variabel yang diubah, (b) perubahan kecenderungan dan efeknya, (c) perubahan stabilitas, (d) perubahan level, dan (e) overlap.

\section{HASIL DAN PEMBAHASAN}

\section{Hasil}

Penelitian dilakukan selama 16 sesi dengan rincian sebagai berikut: pengukuran pada kondisi baseline-1 (A1) dilakukan selama 5 sesi dimulai pada tanggal 5 Maret 2018 sampai dengan 9 Maret 2018. Perolehan nilai yang didapat sebesar $60 \%$ pada sesi pertama, $53 \%$ pada sesi ke-2, 66\% pada sesi ke-3, 66\% pada sesi ke-4, 66\% pada sesi ke-5. Pengukuran pada kondisi intervensi (B) dilakukan selama 6 sesi dimulai pada tanggal 12 Maret 2018 sampai dengan 17 Maret 2018. Perolehan nilai yang didapat sebesar $80 \%$ pada sesi pertama, $80 \%$ pada sesi ke- $2,73 \%$ pada sesi ke- 3 , 93\% pada sesi ke- 4 , 93\% pada sesi ke-5, dan 93\% pada sesi ke-6. Pengukuran pada kondisi baseline-2 (A2) dilakukan selama 5 sesi dimulai pada tanggal 19 Maret 2018 sampai dengan 23 Maret 2018. Perolehan nilai yang didapat sebesar $80 \%$ pada sesi pertama, $73 \%$ pada sesi ke-2, 80\% pada sesi ke-3, 80\% pada sesi ke-4, dan $80 \%$ pada sesi ke-5. Data yang diperoleh pada kondisi baseline-1 (A1), intervensi (B), dan baseline-2 (A2) dapat digambarkan pada grafik 1. Grafik 1 menunjukkan data keseluruhan dari hasil pengukuran yang dilakukan di SLB Smart School Pacet Mojokerto. Garis berwarna biru pada grafik menggambarkan perolehan data pada kondisi baseline-1 (A1), garis berwarna merah menggambarkan perolehan data pada kondisi intervensi (B), garis berwarna hijau menggambarkan perolehan data pada kondisi baseline-2 (A2).

Analisis data pada penelitian ini menggunakan analisis dalam kondisi dan analisis antar kondisi. Hasil analisis dalam kondisi dipaparkan sebagai berikut: Panjang kondisi yang dilakukan pada kondisi baseline-1 (A1) adalah 5 sesi, pada kondisi intervensi (B) adalah 6 sesi, dan pada kondisi baseline-2 (A2) adalah 5 sesi. Estimasi kecenderungan arah pada kondisi baseline-1 (A1) adalah meningkat, karena skor yang diperoleh subjek semakin meningkat.

Estimasi kecenderungan arah pada kondisi intervensi (B) cenderung meningkat. Hal tersebut menunjukkan bahwa intervensi berupa teknik shaping dapat meningkatkan kemampuan menggosok gigi pada anak tunagrahita sedang. Estimasi kecenderungan arah pada kondisi baseline-2 (A2) adalah mendatar. Hal tersebut membuktikan bahwa terdapat pengaruh setelah pemberian intervensi berupa teknik shaping.

Hasil perolehan kecenderungan stabilitas pada kondisi baseline-1 (A1) adalah 80\%. Hal tersebut menunjukkan bahwa data yang diperoleh adalah stabil. Pada kondisi intervensi (B), hasil perolehan kecenderungan stabilitas yaitu $83,83 \%$ yang berarti data stabil. Perolehan kecenderungan stabilitas pada 
kondisi baseline-2 (A2) adalah 100\% yang juga menunjukkan bahwa data stabil.

Pada kondisi baseline-1 (A1), kecenderungan jejak data adalah meningkat. Hal tersebut dikaenakan perolehan nilai yang diperoleh anak adalah meningkat. Kecenderungan jejak data pada kondisi intervensi (B) juga meningkat. Hal tersebut menunjukkan bahwa kemampuan menggosok gigi anak tunagrahita sedang mengalami peningkatan dengan diberikan intervensi berupa teknik shaping. Pada kondisi baseline-2 (A2), kecenderungan jejak datanya adalah mendatar. hal tersebut membuktikan bahwa pemberian intervensi berupa teknik shaping berpengaruh terhadap kemampuan menggosok gigi pada anak tunagrahita sedang. Data pada kondisi baseline-1 (A1) meningkat stabil dengan perolehan rentang 53\%-66\%. Data pada kondisi intervensi (B) meningkat stabil dengan perolehan rentang 73\%-93\%. Data pada kondisi baseline-2 (A2) meningkat stabil dengan perolehan rentang $73 \%-80 \%$. Pada kondisi baseline-1 (A1) menunjukkan tanda (+) yang berarti data mengalami peningkatan. Pada kondisi intervensi (B) juga menunjukkan tanda $(+)$ yang berarti data juga mengalami peningkatan. Pada kondisi baseline-2 (A2) menunjukkan tanda $(=)$ yang berarti data tetap atau stabil. Berdasarkan hasil perhitungan tersebut, maka perolehan hasil analisis visual dalam kondisi pada penilitian dapat dilihat pada tabel 1 . Sedangkan perhitungan untuk analisis antar kondisi dalam penelitian ini dapat dilihat pada tabel 2 .

Tabel 2 menjelaskan hasil perolehan analisis visual antar kondisi pada penelitian ini. Analisis visual antar kondisi dilakukan untuk mengetahui adanya pengaruh pemberian intervensi terhadap target behaviour. Jumlah variabel yang akan diubah pada penelitian ini adalah satu, yaitu pada kondisi baseline-1 (A1) ke kondisi intervensi (B). Perolehan hasil kecenderungan arah antara kondisi baseline-1 (A1) ke kondisi intervensi (B) yaitu meningkat ke meningkat. Hal tersebut menunjukkan bahwa terdapat peningkatan pada sebelum dan sesudah diberikan intervensi. Sedangkan perolehan hasil kecenderungan arah antara kondisi intervensi (B) ke kondisi baseline-2 (A2) yaitu meningkat ke mendatar. Hal tersebut berarti bahwa pemberian intervensi berupa teknik shaping memberikan pengaruh terhadap kemampuan menggosok gigi pada anak tunagrahita sedang secara signifikan. Perubahan kecenderungan stabilitas antara kondisi baseline-1 (A1) ke kondisi intervensi (B) yaitu stabil ke stabil. Perubahan kecenderungan stabilitas antara kondisi intervensi (B) ke kondisi baseline-2 (A2) juga stabil ke stabil.

Kemampuan menggosok gigi anak tunagrahita sedang pada kondisi baseline-1 (A1) ke kondisi intervensi (B) mengalami peningkatan sebesar +14. Sedangkan kemampuan menggosok gigi anak tunagrahita sedang pada kondisi ntervensi (B) ke kondisi baseline-2 (A2) mengalami penurunan sebesar -13 .

Data yang tumpang tindih pada kondisi baseline-1 (A1) ke kondisi intervensi (B) yaitu nol. Hal tersebut menunjukkan bahwa terdapat pengaruh antara pemberian intervensi terhadap target behaviour. Hal itu membuktikan bahwa teknik shaping mampu membentuk kemampuan menggosok gigi secara mandiri pada siswa tunagrahita sedang.

\section{Pembahasan}

Kemampuan Menggosok Gigi Anak Sebelum Diberikan Intervensi

Menurut Kementrian Pendidikan dan Kebudayaan (2014), salah satu ketidakmampuan pada anak tunagrahita sedang adalah dalam hal perilaku adaptif seperti merawat diri, mengurus diri, menolong diri, komunikasi, adaptasi lingkungan, penggunaan waktu luang dan melakukan keterampilan sederhana. Wantah (2007) berpendapat jika bina diri merupakan salah satu proses pendidikan yang diberikan kepada anak tunagrahita sedang agar mampu mengembangkan kemampuan dirinya. Kemampuan awal sebelum diberikan intervensi dapat dilihat pada kondisi baseline-1 (A1). Kemampuan menggosok gigi yang dimiliki anak tergolong masih kurang mampu. Hal tersebut dapat dilihat dari perolehan perhitungan pada kondisi baseline-1 (A1) dengan rincian mean level sebesar 62,2. Estimasi kecenderungan arah pada penelitian ini cenderung meningkat, kecenderungan jejak data yang juga meningkat, dan level perubahan mengalami perubahan sebesar $6 \%$.

Peningkatan yang terjadi pada kondisi ini tidak dipengaruhi oleh adanya intervensi apapun. Pada kondisi ini, anak diberikan perintah untuk menggosok gigi secara mandiri. Pada awalnya anak mengalami kesulitan dalam tahapan-tahapan menggosok gigi. Hal tersebut dikarenakan setiap hari saat di rumah anak masih dibantu oleh orang tua saat menggosok gigi. Peningkatan sebesar $6 \%$ merupakan wujud dari antusiasme anak untuk dapat menggosok gigi secara mandiri.

Kemampuan Menggosok Gigi Anak Setelah Diberikan Intervensi

Pada penelitian ini, anak diberikan intervensi berupa teknik shaping yang berisi tahapan-tahapan menggosok gigi yang benar. Rochjadi (2014) mengemukakan bahwa pentahapan (shaping) ialah membagi kegiatan dalam beberapa pentahapan, bagi pekerjaan/kegiatan yang dimulai dari yang mudah ke yang sukar. Tahapan menggosok gigi yang diberikan sebagai intervensi dimulai dari menyiapkan air di dalam cangkir untuk berkumur, memegang sikat gigi dengan benar, membuka tutup pasta gigi, mengoleskan pasta gigi ke bulu sikat gigi, berkumur, menggosok gigi dari bagian depan, samping dan bagian dalam dengan 
gerakan yang benar dan tekanan yang wajar, berkumur kembali, melap mulut, dan merapikan alat dan bahan yang telah digunakan. Tahapan menggosok gigi merupakan kriteria yang digunakan untuk mencapai target behaviour. Wantah (2002) dalam penelitiannya menyimpulkan bahwa dengan memberikan latihan yang terus menerus maka $77,78 \%$ anak tunagrahita sedang dapat menggosok gigi sesuai dengan prosedur yang diajarkan.

Pada penelitian ini, selama pembelajaran bina diri dengan menggunakan teknik shaping, kemampuan menggosok gigi anak meningkat. Hal ini dibuktikan dari hasil perolehan nilai pada kondisi intervensi. Pada tiap sesi intervensi, anak mengalami peningkatan kemampuan. Pada sesi pertama kondisi intervensi, anak memperoleh nilai sebesar $80 \%$. Pada sesi kedua anak juga memperoleh nilai sebesar $80 \%$. Pada sesi ketiga, nilai yang diperoleh anak menurun menjadi $73 \%$. Penurunan nilai yang diperoleh anak pada sesi ketiga dikarenakan saat tahapan berkumur anak menelan air dengan alasan haus. Selain itu juga dipengaruhi oleh mood anak yang sedang tidak baik. Pada ke sesi keempat kemampuan anak kembali meningkat. Nilai yang diperoleh anak pada sesi keempat sebesar 93\%. Pada sesi kelima dan keenam, anak menunjukkan kestabilan nilai dengan memperoleh nilai sama seperti pada sesi keempat yaitu 93\%. Mean level pada kondisi intervensi sebesar 85,3. Keenderungan arah pada kondisi intervensi cenderung meningkat, jejak data meningkat, dan perubahan level juga mengalami perubahan yaitu sebesar $+13 \%$.

Pengaruh Teknik Shaping untuk Membentuk Kemampuan Menggosok Gigi Anak Tunagrahita Sedang

Pada penelitian ini, anak diberikan intervensi berupa teknik shaping yang berisi tahapan-tahapan menggososk gigi yang benar. Rochjadi (2014) mengemukakan bahwa pentahapan (shaping) yaitu membagi perlakuan ke dalam beberapa pentahapan, kegiatan tersebut dimulai dari yang mudah menuju yang sukar. Penelitian ini dilakukan untuk mengetahui adanya pengaruh teknik shaping terhadap kemampuan menggosok gigi anak tunagrahita sedang. Hal tersebut dapat dilihat dari penilaian kemampuan menggosok gigi anak tunagrahita sedang pada kondisi baseline-1 (A1) dan kondisi intervensi (B). Rentangan nilai pada kondisi baseline-1 (A1) berkisar antara 53\% sampai $66 \%$. Sementara rentangan nilai pada kondisi intervensi (B) mengalami peningkatan yang cukup signifikan yaitu berkisar antara $73 \%$ sampai $93 \%$.

Mean level, estimasi kecenderungan arah dan perubahan level dari kondisi baseline-1 (A1) ke kondisi intervensi (B) mengalami peningkatan. Mean level pada kondisi baseline-1 (A1) sebesar 62,2. Saat telah diberikan intervensi (B) mean level meningkat menjadi 85,3 . Estimasi kecenderungan arah pada kondisi baseline-1 (A1) maupun pada kondisi intervensi (B) sama-sama meningkat, namun peningkatan pada kondisi baseline-1 (A1) tidak sepesat peningkatan pada kondisi intervensi (B). Perubahan level berdasarkan selisih antara data sesi pertama kondisi intervensi (B) dengan data sesi terakhir pada kondisi baseline-1 (A1) sebesar $+13 \%$. Hal tersebut menunjukkan bahwa terdapat peningkatan kemampuan yang signifikan antara sebelum dan selama kondisi intervensi.

Perhitungan data yang tumpah tindih atau presentase overlap pada penelitian ini adalah 0 . Sunanto,dkk (2005) menjelaskan bahwa semakin kecil presentase overlap maka semakin baik pengaruh intervensi terhadap target behaviuor. Berdasarkan pernyataan tersebut, maka dapat dikatakan bahwa peningkatan kemampuan menggosok gigi pada anak tunagrahita sedang merupakan hasil pengaruh dari diberikannya intervensi berupa teknik shaping.

Berdasarkan hasil dari analisis yang telah dilakukan dan disajikan dalam bentuk tabel maupun grafik yang menggunakan desain A-B-A, maka teknik shaping merupakan salah satu teknik yang efektif untuk membentuk kemampuan menggosok gigi pada anak tunagrahita sedang. Perbandingan kemampuan menggosok gigi pada saat sebelum dan setelah diberikan intervensi mengalami peningkatan. Perolehan nilai yang berubah-ubah dipengaruhi oleh kondisi mood anak juga berubah-ubah. Selain itu, juga dipengaruhi oleh konsentrasi anak yang terganggu dengan hal-hal di sekitar.

\section{KESIMPULAN DAN SARAN}

\section{Kesimpulan}

Berdasarkan hasil analisis dan pembahasan yang telah dipaparkan pada bab sebelumnya, maka dapat disimpulkan bahwa penggunaan teknik shaping mampu memberikan pengaruh yang signifikan untuk membentuk kemampuan bina diri menggosok gigi pada anak tunagrahita sedang.

\section{Saran}

Berdasarkan kesimpulan tersebut maka diharapkan pembelajaran bina diri yang dilakukan oleh guru maupun orang tua dapat menggunakan teknik pembelajaran yang sesuai sehingga memudahkan anak tunagrahita sedang untuk memahami materi yang diberikan.

\section{DAFTAR RUJUKAN}

Basuni, M. (2012). Pembelajaran Bina Diri Pada Anak Tunagrahita Ringan. Jurnal Pendidikan Khusus Vol IX No. 1, 12-22. Dari https://journal.uny.ac.id/ index.php/jpk/article/view/6725

Delphie, B. 2006. Pembelajaran Anak Tunagrahita. Bandung : Refika Aditama 
Efendi, M. (2009). Pengantar Psikopedagogik Anak Berkelainan. Jakarta: Bumi Aksara

Miltenberg, G R. (2014). Behaviour Modification. United State of America : Thomson Learning, inc

Muhammad, H. (2014). Program Pengembangan Diri untuk Peserta Didik Tunagrahita. Jakarta : Kementrian Pendidikan dan Kebudayaan

Prawitasari, Johana E. 2011. Psikologi Klinis. Jakarta : Airlangga

Purwanta, Edi. 2012. Modifikasi Perilaku. Yogjakarta : Pustaka Pelajar

Rahmawati, H. (2009). Modifikasi Perilaku Manusia. Universitas Negeri Malang : Fakultas Ilmu Pendidikan

Rochjadi, H. (2014). Program Kekhususan Pendidikan Anak Tunagrahita. Bandung : Pusat Pengembangan dan Pemberdayaan Pendidikan dan Tenaga Kependidikan Taman Kanak-Kanak dan Pendidikan Luar Biasa.
Runtukahu, T J. (2012). Analisis Perilaku Terapan untuk Guru. Yogjakarta : Ar -Ruzz

Somantri. (2012). Psikologi Anak Luar Biasa. Bandung : PT. Refika Aditama

Sugiyono. (2015). Metode Penelitian Pendidikan. Bandung : Alfabeta

Sunanto, J., Takeuchi, K., Nakata, H. (2005). Pengantar Penelitian Dengan Subyek Tunggal. Tsukuba: CRICED University of Tsukuba

Wantah, J. (2007) . Pengembangan Kemandirian Anak Tunagrahita Mampu Latih. Jakarta : Departemen Pendidikan Nasional, Direktorat Jenderal Pendidikan Tinggi, Direktorat Ketenagaan 